\title{
Novel Botulinum Neurotoxins: Exploring Underneath the Iceberg Tip
}

\author{
Domenico Azarnia Tehran *,+ (i) and Marco Pirazzini * \\ Department of Biomedical Sciences, University of Padova, Via Ugo Bassi 58/B, 35131 Padova, Italy \\ * Correspondence: azarnia@fmp-berlin.de (D.A.T.); marco.pirazzini@unipd.it (M.P.); \\ Tel.: +49-309-479-3206 (D.A.T.); +39-049-827-6056 (M.P.) \\ † Present address: Leibniz-Forschungsinstitut für Molekulare Pharmakologie (FMP), Robert-Rössle-Straße 10, \\ 13125 Berlin, Germany.
}

Received: 15 April 2018; Accepted: 8 May 2018; Published: 10 May 2018

\begin{abstract}
Botulinum neurotoxins (BoNTs), the etiological agents of botulism, are the deadliest toxins known to humans. Yet, thanks to their biological and toxicological features, BoNTs have become sophisticated tools to study neuronal physiology and valuable therapeutics for an increasing number of human disorders. BoNTs are produced by multiple bacteria of the genus Clostridium and, on the basis of their different immunological properties, were classified as seven distinct types of toxin. BoNT classification remained stagnant for the last 50 years until, via bioinformatics and high-throughput sequencing techniques, dozens of BoNT variants, novel serotypes as well as BoNT-like toxins within non-clostridial species have been discovered. Here, we discuss how the now "booming field" of botulinum neurotoxin may shed light on their evolutionary origin and open exciting avenues for future therapeutic applications.
\end{abstract}

Keywords: botulinum neurotoxins; botulism; serotypes; subtype; neuromuscular junction

Key Contribution: High-throughput sequencing techniques and computational biology are unraveling an unexpected variability of Botulinum Neurotoxins. This information may shed light on their evolutionary origin and may be exploited for novel therapeutic applications.

\section{Introduction}

Botulinum neurotoxins (BoNTs) are the etiological agents of botulism, a rare but severe disease for vertebrates, causing neuroparalysis at peripheral nerve endings [1-3]. BoNTs are metalloproteases that cleave members of the "soluble $N$-ethylmaleimide-sensitive-factor attachment receptor" (SNARE) protein family, namely, vesicle-associated membrane protein (VAMP, also known as synaptobrevin), synaptosomal-associated protein 25 (SNAP-25) and syntaxins (mainly syntaxin-1A/1B). SNARE proteins mediate the fusion of synaptic vesicles with the neuronal presynaptic plasma membrane $[4,5]$ and their proteolysis leads to a failure of neurotransmission, thereby causing the deadly flaccid paralysis typical of botulism $[2,3,6]$. BoNTs are a matter of concern, as they are the deadliest toxins known to humans, with an estimated lethal dose in the low ng/Kg range [1]. At the same time, the neurospecific activity, reversibility and limited diffusion upon local injection make them safe and successful drugs for a steadily increasing number of human disorders characterized by hyperfunction of peripheral nerve terminals [1,7-9]. In addition, BoNTs are considered as valuable and sophisticated tools for studying neuron physiopathology [10-12]. For all these reasons, BoNTs are considered Janus-faced molecules, being both some of the safest drugs on the market and potential bioweapons at the same time [13]. 
BoNTs are produced by sporulating and anaerobic Gram-positive bacteria of the genus Clostridium, which consists of more than 150 species. These bacteria are ubiquitous in the environment, where they are mainly present as spores that germinate in favorable conditions (anaerobiosis, nutrient availability and low $\mathrm{pH}$ ) [3]. During vegetative growth, not solely the foremost Clostridium botulinum, but additional species, such as Clostridium butyricum, Clostridium baratii and Clostridium argentinensis, become toxigenic and produce the neurotoxins. Using antisera from animals immunized with specific toxin types, BoNTs have been classified into seven different serotypes indicated with alphabetical letters (from BoNT/A to /G) $[2,14]$. After the discovery of the last serotype (BoNT/G), such a nomenclature remained unchanged for about 50 years. Then, since the introduction of DNA sequencing methodologies, this static view has been continuously evolving and many alternative variants of BoNT serotypes have been emerging. Mosaic toxins, deriving from the hybridization of two serotypes, or toxins related to a parental serotype but displaying divergent amino acid sequences, referred to as subtypes, were identified $[15,16]$. Presently, faster and cheaper high-throughput sequencing techniques, combined with computational biology, are again changing the scenario [16]. Novel serotypes, many subtypes and mosaic toxins are now more easily detected and the number of BoNTs is constantly and rapidly increasing. Moreover, genomic data-mining is now revealing the unexpected and remarkable finding that BoNT-like genes are also present within non-clostridial species such as Weissella, Enterococcus and Chryseobacterium [17,18].

Here, we review the recent findings about this booming field of botulinum neurotoxins and discuss how these "novel BoNTs" may shed light on their evolutionary origin and inspire researchers to design novel therapeutic tools to expand the present clinical usage.

\section{BoNTs' Molecular Architecture and Mechanism of Nerve Endings Intoxication}

The structure and the mechanism of action of BoNTs have been shaped during evolution to exploit essential features of neuron physiology $[2,16]$. Serotypes have relatively low sequence identity but display a highly preserved molecular architecture arranged in a catalytic light chain of $50 \mathrm{kDa}(\mathrm{L})$ and a heavy chain of $100 \mathrm{KDa}(\mathrm{H})$, held together by a strictly conserved interchain disulfide bond (Figure 1) $[19,20]$. According to their functions, $\mathrm{H}$ and $\mathrm{L}$ can be divided into four subdomains: (i) HC-C ( $25 \mathrm{kDa})$ mediates the binding and the subsequent internalization/trafficking of the toxin within nerve terminals [21,22]; (ii) $\mathrm{HC}-\mathrm{N}(25 \mathrm{kDa})$ contributes to the binding by interacting with membrane lipid microdomains $[23,24]$ and by forming, at the interface with $\mathrm{HC}-\mathrm{C}$, a crevice where $\mathrm{N}$-glycans of glycosylated receptors can be accommodated [25,26]; (iii) HN (50 kDa) mediates the translocation of the catalytic protomer from the luminal part of endocytic compartments into the cytosol [27-29]; and (iv) L is a zinc metalloprotease specific for the SNARE proteins [30-32], the three essential components governing the neuroexocytosis process (Figure 1) [4,5].

Extensive studies using in vitro and in vivo models pinpointed the five-step mechanism by which BoNTs exert their highly selective and potent neurotoxic activity [33-36]. Once in the perineuronal fluid compartment, BoNTs bind the unmyelinated presynaptic plasma membrane of skeletal and autonomic nerve endings via two independent receptors $[1,21,22,37]$. With no known exception, all BoNTs bind polysialogangliosides, a class of glycolipid molecules exclusively expressed on neuronal plasma membranes. Such a binding mediates the accumulation of BoNTs onto the membrane of peripheral nerves and facilitates the interaction with a second receptor, allowing toxin internalization [2,37]. This functional receptor is the luminal domain of a synaptic vesicle protein, which is different among serotypes (Table 1). BoNT/A binds one isoform of the transmembrane protein SV2 (SV2A, B or C) [38-40] like BoNT/E, except for SV2C [41]. BoNT/B, BoNT/DC and BoNT/G interact with the luminal domain of synaptotagmin-1/2 [42-44]. Recent studies suggest that SV2C glycosylation plays a pivotal role on BoNT/A binding/internalization [25,45]. Considering that protein glycosylation can vary among individuals [46-48], this finding may explain why humans display variable susceptibility to the same therapeutic doses of BoNT/A [1]. Even though the importance of glycosylation in protein receptor has been shown only for the BoNT/A and SV2C, synaptotagmin-1/2 
also are glycosylated nearby the BoNT binding motif, leaving open the possibility of a role for $N$-glycans in the binding of BoNT/B, BoNT/DC and BoNT/G [26]. Interestingly, BoNT/DC was recently shown to have a ganglioside binding site that, differently from all BoNTs, recognizes a single sialic acid residue rather than extended portions of the polysialoganglioside structure. As a consequence, BoNT/DC has been suggested to bind noncomplex gangliosides and a broad range of binding partners harboring sialic acids on their molecule [49]. This feature of BoNT/DC is surprising, as it is difficult to reconcile its extreme toxicity $\left(\mathrm{LD}_{50} \sim 0.05 \mathrm{ng} / \mathrm{kg}\right.$ [50]) with such a broad and unspecific binding capacity. BoNT/D binding remains controversial, with data indicating multiple bindings to polysialogangliosides and other data showing the need for SV2 proteins [51-53]. So far, no protein receptors have been reported for BoNT/C, suggesting that it may entirely depend on the interaction with polysialogangliosides [54-56]. Upon binding, BoNT/A is rapidly internalized by synaptic vesicles [57-59], whereas the endocytic compartment used by other BoNT serotypes remains to be identified. Thereafter, the $\mathrm{L}$ chain has to reach the cytosol. The translocation process requires a concerted rearrangement of the $\mathrm{HN}$ domain and of the $\mathrm{L}$ chain, which is triggered by the acidification of the endocytic compartment. At low pH, BoNTs form a membrane channel, which is associated with the passage of the L chain [60-62]. Despite different mechanisms having been envisaged, the real molecular process is still poorly understood [27-29]. However, it is clear that some unfolding of L is necessary and that the interchain disulfide bond must remain intact during the initial phase of membrane translocation. Consequently, the disulfide bond must be reduced, and L has to be properly refolded to be released into the cytosol in a functional form [29,36,63]. Recently, it has been proposed that a molecular complex comprising the thioredoxin reductase/thioredoxin ( $\operatorname{Trx} / \operatorname{TrxR})$ system and the chaperone Hsp90, which are both present on the cytosolic side of the SV membrane, fulfills both the reduction and the refolding of the $\mathrm{L}$ chain $[35,64,65]$. Once released in the cytosol, the L chains of the different serotypes cleave distinct peptide bonds of specific SNARE proteins [30,31]: BoNT/B, /D, /F and /G hydrolyze VAMP-1/2, whereas BoNT/A and BoNT/E cleave the membrane protein SNAP-25. BoNT/C was the unique toxin found to cleave more than one SNARE member, that is, both SNAP-25 and syntaxins-1/2 (Figure 2 and Table 1). However, with the recent discovery of novel BoNTs (discussed below), this feature may no longer be considered as a BoNT/C peculiarity. In any case, the cleavage of any one of these proteins blocks the neuroexocytosis process, causing botulism and, in general, the various membrane fusion events mediated by these proteins in eukaryotic cells. The intraneuronal lifetime of the L chains is a primary determinant of the persistence of both BoNTs' pharmacological activity and of botulism severity and duration. The order of duration of action in mice and humans is: BoNT/A BoNT/C > BoNT/B BoNT/D, BoNT/F, and BoNT/G BoNT/E [1]. However, BoNT/D is almost inactive in humans but very potent in rodents [66].

Table 1. Binding receptors, amino acids of the metalloprotease active sites, substrate specificity and cleaved peptide bonds of BoNT variants.

\begin{tabular}{|c|c|c|c|c|c|c|}
\hline Serotype & Protein Receptor & $\begin{array}{l}\text { Ganglioside } \\
\text { Receptor }\end{array}$ & $\begin{array}{l}\text { HC-C GBP } \\
\text { (SXWY) }\end{array}$ & $\begin{array}{l}\text { Metalloprotease } \\
\text { Motif (HExxH) }\end{array}$ & Substrates & $\begin{array}{l}\text { Cleavage } \\
\text { Sites }\end{array}$ \\
\hline \multirow[t]{2}{*}{ BoNT/A } & $\mathrm{N}$-glycosylated & GT1b & \multirow[t]{2}{*}{ SNWY } & \multirow[t]{2}{*}{ HELIH } & SNAP-23 & T202-R203 \\
\hline & SV2A-B-C & GD1a & & & SNAP-25 & Q197-R198 \\
\hline \multirow{3}{*}{ BoNT/B } & \multirow{3}{*}{ Synaptotamin-1/2 } & \multirow{3}{*}{$\begin{array}{l}\text { GT1b } \\
\text { GD1a }\end{array}$} & \multirow{3}{*}{ SKWY } & \multirow{3}{*}{ HELIH } & VAMP-1 & Q78-F79 \\
\hline & & & & & VAMP-2 & Q76-F77 \\
\hline & & & & & VAMP-3 & Q63-F64 \\
\hline \multirow{3}{*}{ BoNT/C } & \multirow{3}{*}{ none * } & \multirow{3}{*}{$\begin{array}{l}\text { GT1b } \\
\text { GD1b }\end{array}$} & \multirow{3}{*}{$(\mathrm{W}) \mathrm{KNY}$} & \multirow{3}{*}{ HELNH } & SNAP-25 & R198-A199 \\
\hline & & & & & Syntaxin-1A,-2,-3 & K253-A254 \\
\hline & & & & & Syntaxin-1B & $\mathrm{K} 252-\mathrm{A} 253$ \\
\hline \multirow{3}{*}{ BoNT/D } & \multirow{3}{*}{$\begin{array}{c}N \text {-glycosylated } \\
\text { SV2A-B-C }\end{array}$} & GT1b & \multirow{3}{*}{$(\mathrm{W}) \mathrm{VNY}$} & \multirow{3}{*}{ HELTH } & VAMP-1 & K61-L62 \\
\hline & & GD1b & & & VAMP-2 & K59-L60 \\
\hline & & GD2 & & & VAMP-3 & K46-L47 \\
\hline \multirow{3}{*}{ BoNT/DC } & \multirow{3}{*}{ Synaptotamin-1/2 } & \multirow{3}{*}{$\begin{array}{l}\text { Sialic acid } \\
\text { residue }\end{array}$} & \multirow{3}{*}{ SNYIS } & \multirow{3}{*}{ HELTH } & VAMP-1 & K61-L62 \\
\hline & & & & & VAMP-2 & K59-L60 \\
\hline & & & & & VAMP-3 & K46-L47 \\
\hline
\end{tabular}


Table 1. Cont.

\begin{tabular}{|c|c|c|c|c|c|c|}
\hline Serotype & $\begin{array}{l}\text { Protein } \\
\text { Receptor }\end{array}$ & $\begin{array}{c}\text { Ganglioside } \\
\text { Receptor }\end{array}$ & $\begin{array}{l}\text { HC-C GBP } \\
\text { (SXWY) }\end{array}$ & $\begin{array}{l}\text { Metalloprotease } \\
\text { Motif (HExxH) }\end{array}$ & Substrates & $\begin{array}{l}\text { Cleavage } \\
\text { Sites }\end{array}$ \\
\hline \multirow{2}{*}{ BoNT/E } & $N$-glycosylated & GT1b & \multirow{2}{*}{ STWY } & \multirow{2}{*}{ HELIH } & SNAP-23 & K185-I186 \\
\hline & SV2A-B & GD1a & & & SNAP-25 & R180-I181 \\
\hline \multirow{3}{*}{ BoNT/F } & \multirow{3}{*}{$\begin{array}{l}N \text {-glycosylated } \\
\text { SV2A-B-C }\end{array}$} & \multirow{3}{*}{$\begin{array}{l}\text { GT1b } \\
\text { GD1a }\end{array}$} & \multirow{3}{*}{ SSWY } & \multirow{3}{*}{ HELIH } & VAMP-1 & Q60-K61 \\
\hline & & & & & VAMP-2 & Q58-K59 \\
\hline & & & & & VAMP-3 & Q45-K46 \\
\hline \multirow{3}{*}{ BoNT/F5 } & Unknown & Unknown & \multirow{3}{*}{ SSWY } & \multirow{3}{*}{ HELIH } & VAMP-1 & L56-E57 \\
\hline & (similar to & (similar to & & & VAMP-2 & L54-E55 \\
\hline & BoNT/F?) & BoNT/F?) & & & VAMP-3 & L41-E42 \\
\hline \multirow{3}{*}{$\begin{array}{c}\text { BoNT/H } \\
\text { (BoNT/HA, } \\
\text { BoNT/FA) }\end{array}$} & \multirow{3}{*}{$\begin{array}{c}N \text {-glycosylated } \\
\text { SV2C }\end{array}$} & Unknown & \multirow{3}{*}{ SNWY } & \multirow{3}{*}{ HELIH } & VAMP-1 & L56-E57 \\
\hline & & (similar to & & & VAMP-2 & L54-E55 \\
\hline & & BoNT/A?) & & & VAMP-3 & L41-E42 \\
\hline \multirow{3}{*}{ BoNT/G1 } & \multirow{3}{*}{ Synaptotamin-1/2 } & \multirow{3}{*}{$\begin{array}{l}\text { GT1b } \\
\text { GD1a }\end{array}$} & \multirow{3}{*}{ SQWY } & \multirow{3}{*}{ HELIH } & VAMP-1 & A83-A84 \\
\hline & & & & & VAMP-2 & A81-A82 \\
\hline & & & & & VAMP-3 & A68-A69 \\
\hline \multirow{6}{*}{ BoNT/X } & \multirow{6}{*}{ Unknown } & \multirow{6}{*}{ Unknown } & \multirow{6}{*}{ SAWY } & \multirow{6}{*}{ HELVH } & VAMP-1 & R68-A69 \\
\hline & & & & & VAMP-2 & R66-A67 \\
\hline & & & & & VAMP-3 & R53-A54 \\
\hline & & & & & VAMP-4 & K86-S87 \\
\hline & & & & & VAMP-5 & R40-S41 \\
\hline & & & & & Ykt6 & K173-S174 \\
\hline BoNT/Wo & Unknown & Unknown & Not present $* *$ & HEMTH & VAMP-2 & W89-W90 \\
\hline \multirow{6}{*}{$\begin{array}{l}\text { BoNT/En } \\
(\mathrm{eBoNT} / \mathrm{J})\end{array}$} & \multirow{6}{*}{ Unknown } & \multirow{6}{*}{ Unknown } & \multirow{6}{*}{ SAWY } & \multirow{6}{*}{$\mathrm{HELCH}$} & SNAP-25 & K69-D70 \\
\hline & & & & & VAMP-1 & A69-D70 \\
\hline & & & & & VAMP-2 & A67-D68 \\
\hline & & & & & VAMP-3 & A54-D55 \\
\hline & & & & & Syntaxin-1B & K145-D146 \\
\hline & & & & & Syntaxin-4 & K191-D192 \\
\hline
\end{tabular}

* BoNT/C binding and internalization may be independent from protein receptors. Polysialogangliosides involved in toxin internalization are also indicated. BoNT/DC is unique among BoNTs, not necessarily needing the interaction with polysialogangliosides. BoNT/X and BoNT/En contain the ganglioside binding pocket domain (GBP), but the dual receptor binding process has not been yet proven. ** Conserved residues forming the ganglioside binding pocket (GBP) are not present in the putative binding domain of BoNT/Wo, which may have a different binding mechanism. The enzymatic substrates and cleavage sites experimentally proven are indicated with mouse numbering. SNAP: synaptosomal-associated protein; VAMP: vesicle-associated membrane protein.
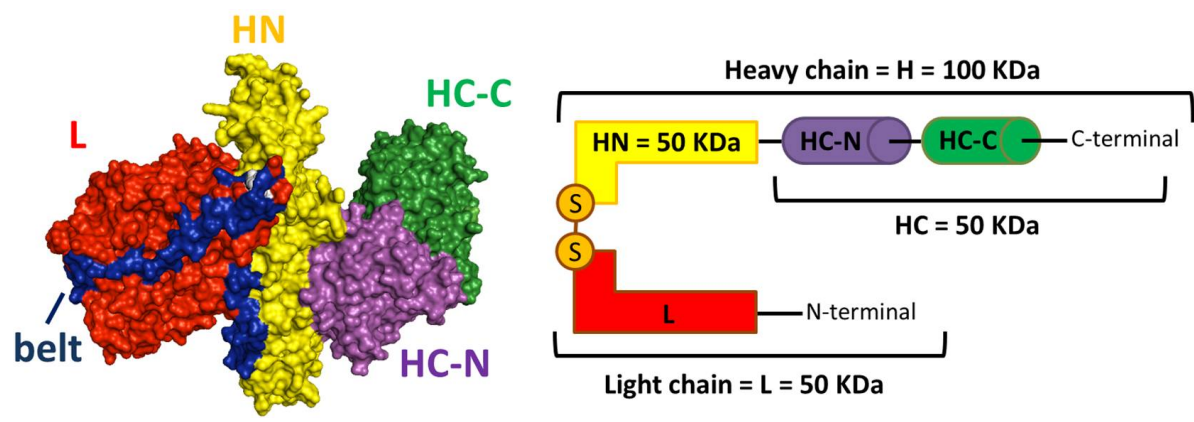

Figure 1. Dichain molecular architecture of botulinum neurotoxins (BoNTs) consisting of four functional subdomains. The crystal structure of BoNT/A (PDB: 3BTA [19]) is shown as a space-filling model (left panel). The functional subdomains are labeled in different colors: HC-C (in green) and HC-N (in purple) mediate toxin binding to the neuronal plasma membrane; HN (in yellow) mediates the translocation of L metalloprotease (in red) into the cytosol. HN and the L chain are kept together via the interchain disulfide bond (in white) and by extensive protein-protein interactions also involving a string of $\mathrm{HN}$ residues, known as the belt (in blue), that entirely encircles the catalytic domain. In the right panel, the dichain structure and the functional subdomains are shown as a schematization with the same colors. 

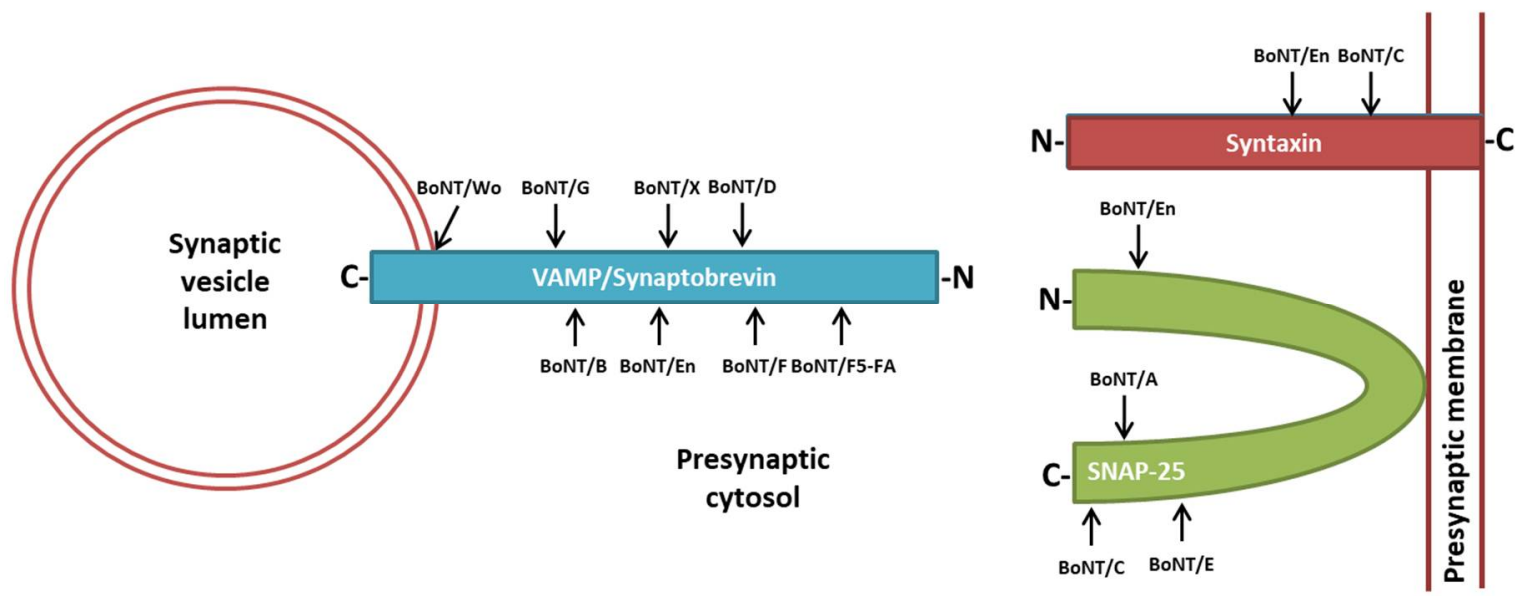

Figure 2. Cleavage sites within SNARE (soluble $N$-ethylmaleimide-sensitive-factor attachment receptor) proteins by the seven BoNT serotypes (from BoNT/A to /G) and by the newly identified BoNT/FA (also known as BoNT/HA or BoNT/H), BoNT/Wo, BoNT/X and BoNT/En (also known as eBoNT/J).

\section{Botulinum Neurotoxins Variability and Classification}

Emile van Ermengem was the first to isolate a C. botulinum strain producing a neuroparalyzing agent in $1895[67,68]$. Five years later, by using antisera generated using neurotoxins from specific C. botulinum strains, Leuchs demonstrated that antisera were not cross-neutralizing and that BoNTs could be antigenically different [15]. With the same approach, a total of seven different toxin types were isolated in the following 50 years (in chronological order: BoNT/C, BoNT/D, BoNT/E, BoNT/F and BoNT/G), leading to the definition of BoNT serotypes and to their historical classification. Serotype definition was challenged when an antiserum raised against BoNT/C (strain Stockholm) neutralized BoNT/D (South Africa strain). Later, it was shown that such a cross-reactivity was due to the genetic recombination of bacterial strains, which led to the generation of a mosaic toxin composed by the $\mathrm{L}$ chain of BoNT/D and the H chain of BoNT/C $[69,70]$. Thereafter, a new designation was introduced for the neurotoxin produced by the strain "South Africa" (i.e., BoNT/DC) to indicate the chimeric nature of the toxin. Several mosaics between BoNT/D and BoNT/C with various domain combinations were subsequently characterized [71-74].

With the development of next generation sequencing, the genetic analysis of clostridial strains responsible for human and animal cases of botulism became systematic. As a result, by sequencing thousands of biological samples, it was observed that neurotoxigenic clostridia have extensive heterogeneity in terms of genome organization, clustering of toxin genes and, most importantly, toxin's amino acid sequence composition [14,75-79]. Novel toxins have been isolated and termed "subtypes" (dubbed as the parental serotype followed by a number; e.g., BoNT/A1, BoNT/A2, etc.), indicating a BoNT similar to the parental serotype but divergent for amino acid composition. Currently, more than 40 unique BoNTs have been identified, which display heterogeneity ranging from very little $(<1 \%)$ to higher than $35 \%[15,76]$. Variability represents another Janus-faced property of BoNTs: on one hand, it challenges the current attempts of controlling BoNT pathogenicity via immunological methods; on the other, some of these subtypes could be endowed with peculiar features to be exploited for therapeutic purposes [1,34]. Indeed, apart from antigenicity, variations in the amino acid composition can significantly alter BoNTs' toxicological features. Even minor amino acid replacements can modify neuronal binding capability/selectivity, catalytic activity, intraneuronal lifetime of the L chain or its translocation efficiency. Despite that functional characterization of these subtypes has been very limited so far, some examples have been put forward. Most of the studies have been focused on BoNT/A toxins due to the large use of BoNT/A1 in human therapy [80-82]. BoNT/A2 displays faster entry into neurons and elicits a faster paralysis with lower spreading upon local injection than 
BoNT/A1, two very appealing features for human therapy [83-85]. BoNT/A3 is much less potent and persistent than BoNT/A1, whereas BoNT/A4 displays poor protease activity [81,84]. BoNT/A5 seems to have a toxicological profile similar to BoNT/A1 [84], while BoNT/A8 has reduced catalytic activity and overall lower toxicity [86]. Much less work has been carried out for other subtypes. One relevant result is about the different protease activity of BoNT/F5 compared to BoNT/F1 that, even though cleaving the same substrate VAMP-1/2, hydrolyzes distinct peptide bonds (Figure 2 and Table 1) [87]. Another interesting investigation showed that BoNT/B2 has much higher affinity than BoNT/B1 for synaptotagmin-2 [88]. This is relevant for therapy because BoNT/B2 may have a more favorable pharmacological profile in the treatment of neuromuscular disorders than BoNT/B1, which is currently approved for human therapy but displays some side effects due to the spreading to autonomic nerves [89]. In fact, BoNT/B2 is expected to display a preferential binding to motor nerve terminals, which constitutively express synaptotagmin-2 but not synaptotagmin-1 [90], rather than to autonomic nerve terminals that predominantly express synaptotagmin-1 [91].

Since BoNT variants are being identified with increasing frequency and they can differ to a very minimal extent, the nomenclature around these neurotoxins is becoming difficult to manage. To avoid that, toxins with identical sequences may be given different designations or, conversely, novel toxins with unique sequences may be given the same designations in 2017, an ad hoc committee consisting of over 20 researchers proposed that (i) a centralized procedure should be undertaken to designate putative novel toxins [15] and that (ii) newly discovered neurotoxin variants must differ from other neurotoxins by more than $2.6 \%$ at the amino acid level. Yet, this designation does not take into account the biological, functional and toxicological properties of the subtypes which could take place even with sequence variation below this arbitrary threshold. As an example, replacement of only three amino acids in BoNT/C L chain almost completely abrogates SNAP-25 cleavability (without significant alteration of syntaxin cleavability) and this remarkably impacts BoNT/C potency and intraneuronal lifetime $[92,93]$. Though these mutants are not naturally occurring, their activity strongly suggests that even very minor modifications can significantly affect BoNT toxicological properties.

\section{BoNT/H (Also Known as BoNT/FA or BoNT/HA): A Complicated Story}

In 2013, after four decades from the isolation of the last BoNT serotype (BoNT/G), a new toxin produced by a bivalent $C$. botulinum strain was isolated from a human infant botulism case. This toxin fulfilled the classic criteria of "new serotype" because it was not neutralized in the mouse bioassay by a mixture of monovalent antitoxins or by the US Army heptavalent antitoxin. Accordingly, it was designated as BoNT/H [94,95]. However, the designation was questioned [96] and a genetic investigation of the toxin gene revealed that BoNT/H shares $\approx 80 \%$ identity with BoNT/F5 in its catalytic domain, $\approx 84 \%$ with BoNT / A1 in its binding domain and displays a translocation domain similar to BoNT/F1 [97]. This suggests that, from a genetic point of view, BoNT/H is a BoNT/F5A1 hybrid, and functional studies-showing that its protease activity is identical to that of BoNT/F5 against VAMP [98] and by binding to SV2 as BoNT/A1 [99]—corroborated this possibility. Moreover, since a second study showed that BoNT/H can be neutralized by existing antisera [97], BoNT/H was renamed "BoNT/FA". However, neutralization efficiency with respect to reference toxins is much lower, ranging from 20 -fold to $>500$-fold, depending on the antitoxin used. Notably, by using monoclonal antibodies, it was shown that only antibodies specific for BoNT/A, but not for BoNT/F, bind to BoNT/H (BoNT/FA) and display neutralization capacity [100], suggesting that the L-HN of the toxin is immunologically unique. As a consequence, a third name, BoNT/HA, was proposed to underline the absence of BoNT/F immunological properties and the high homology to the BoNT/A binding domain [99].

From a functional point of view, BoNT/H (i.e., BoNT/FA or BoNT/HA) is very active on cultured neurons with no species-specificity (human vs. rodents) and its light chain is markedly more efficient than that of other VAMP-cleaving toxins. At the same time, its toxicological profile in vivo is unusual, as it displays a relatively low potency and a slow progression of botulism symptoms [101]. Slow 
onset of paralysis is also observed when BoNT/H (i.e., BoNT/FA or BoNT/HA) is locally injected, yet it unexpectedly produces a relatively persistent duration of action, even slightly longer than BoNT/B [102].

Altogether, these results suggest that BoNT/H (i.e., BoNT/FA or BoNT/HA) is a very peculiar toxin and further demonstrate that BoNT variants can be endowed with unique serological, genetic and functional features which make difficult their classification by arbitrary definitions. In general, the complicated story of BoNT/H (i.e., BoNT/FA or BoNT/HA) perfectly embodies the challenge that researchers have to deal with to classify toxins trying to reconcile immunological, genetic and functional properties. Currently, three designations for BoNT/H, based on one of these features, are indistinguishably used and indistinguishably (not) accepted [15]. Such a nomenclature may be complicated to manage and may become confusing if novel toxins with similar requirements are discovered.

\section{Identification and Characterization of BoNT/X}

In 2017, Zhang et al. found in the chromosome of a C. botulinum (strain 111) the gene of a putative neurotoxin displaying significant divergence with respect to known BoNTs. Strain 111 was responsible for a case of infant botulism in Japan, where BoNT/B2, encoded on a plasmid, was identified as the neurotoxic agent [103]. This putative toxin displayed the typical BoNT molecular architecture (Figure 1) and several key features essential for neurotoxicity, including the interchain disulphide bond, the residues forming a ganglioside binding pocket and the metalloprotease consensus sequence (Table 1). Even though it remains to be established whether this putative BoNT is actually expressed by the bacterium (loss of the plasmid encoding for BoNT/B2 abrogates toxicity [104]), a recombinant derivative cannot be recognized and neutralized by existing antisera. Accordingly, if this toxin would be naturally produced it could be certainly considered a new serotype and designated as BoNT / X [105]. Using a recombinant L chain and mass spectrometry, it was found that BoNT/X cleaves VAMP-1/-2/-3 at a unique peptide bond (R66-A67), differently from all other VAMP-specific BoNTs (Figure 2 and Table 1). Unexpectedly, BoNT / X also cleaves VAMP-4 (K87-S88), VAMP-5 (R40-S41) and Ykt6 (K173-S174), three SNARE proteins involved in various membrane-trafficking events among different cellular compartments but not directly involved in neuroexocytosis. VAMP-7, VAMP-8 and Sec22b are instead resistant. Given that the SNARE-selectivity of BoNTs relies on multiple, extended and very specific interactions between the L chain and the substrate [1,106-109], the ability of BoNT/X to cleave such a copious number of VAMP isoforms is very surprising. Even more surprising is the fact that, notwithstanding such a broad specificity, LC / X chain cleaves VAMP-2 with a 10-fold higher efficiency than LC/B [110]. Moreover, a BoNT/X derivative consisting of two nontoxic fragments enzymatically ligated (LC-HN and HC) can enter neurons and cause flaccid paralysis in vivo, thus suggesting that it can, in principle, cause botulism.

Further studies are needed to determine: (i) Which is (are) the receptor(s) mediating cellular uptake? (ii) What are the functional consequences of the simultaneous inactivation of so many VAMP isoforms in neurons? and (iii) What is the potency in vivo relative to other BoNTs? Moreover, future structural and biochemical analyses may explain in which way BoNT/X light chain can interact and cleave so many different substrates. These data will be helpful both to study the physiological role(s) of specific neuronal VAMP isoforms and to possibly engineer BoNT proteases against specific target(s) for novel applications.

\section{Discovery and Biological Characterization of the First Non-Clostridial Botulinum-Like Toxin}

In 2015, Mansfield et al. found in the genome of Weissella oryzae SG25 an open reading frame (then dubbed Wo-orf1) sharing substantial nucleotide sequence homology with bont genes but lacking some essential features of BoNTs and the additional genes encoding for the neurotoxin accessory proteins typical of BoNT gene clusters [111]. W. oryzae is a Gram-positive bacteria member of the phylum Firmicutes, like Clostridium, but it belongs to the separate class of Lactobacillales. It was first isolated 
from fermented food and rice grains, an ecological niche shared with C. botulinum [112]. The authors suggested the possibility that Wo-orf1 was laterally transferred into the $W$. oryzae genome from an unknown source, possibly from a neurotoxigenic Clostridium present within the same environment.

Despite low sequence identity (14-16\%), structural modeling of Wo-ORF1 predicted substantial folding homology with BoNTs, with the putative L chain (Wo-ORF1-LC), HN domain and the HC domain (Wo-ORF1-HC) folding very similarly to the corresponding domains in BoNT/B. In addition, Wo-ORF1-LC contains the critical HExxH zinc-coordinating motif (Table 1) and the additional Arg and Tyr (residues 369 and 372 of BoNT/B) of the second shell of zinc coordination, essential for the metalloprotease activity [113]. At the same time, significant differences exist. Wo-ORF1 does not display the conserved cysteine subtending the interchain disulphide bond, essential to generate the mature dichain structure typical of BoNTs (Figure 1). Moreover, Wo-ORF1-HC does not contain the key amino acids arranging the GBP and the interface for known protein receptors (synaptotagmin or SV2). Nevertheless, in order to characterize the biological features of Wo-ORF1, Wo-ORF1-LC and Wo-ORF1-HC were produced by recombinant methods [114]. In keeping with structural homology but substantial amino acid divergence, Wo-ORF1-LC and Wo-ORF1-HC were not immunoreactive with standard antisera, except for a very weak cross-reactivity with anti-BoNT/C and -BoNT/D [114]. Importantly, Wo-ORF1-LC was found to cleave VAMP-2 at the peptide bond W89-W90 located within the juxtamembrane segment. This site plays an essential role during neurotransmitter release $[115,116]$ and it is conserved in several VAMP isoforms (VAMP-1/-3/-4/-8) of vertebrates (human, mouse, rat and rabbit), invertebrates (C. elegans) and plants. Wo-ORF1-LC activity is thus expected to cause the release of the entire cytosolic domain of VAMP-2, thus preventing the assembly of the SNARE complex and the subsequent process of neuroexocytosis. Building upon these results and on the lack of significant cross-reactivity of Wo-ORF1 subdomains with existing antisera, Zornetta et al. propose that the orf-1 gene of $W$. oryzae codes for a novel BoNT-like toxin tentatively termed BoNT/Wo [114]. Notably, whether and in which environmental conditions W. oryzae naturally expresses BoNT/Wo should be investigated. In fact, given the significant differences in the binding domain, it is more than possible that BoNT/Wo may display, besides distinct binding and internalization mechanisms, a host target different from vertebrate, a possibility also indicated by its peculiar cleavage site. A careful analysis of $W$. oryzae ecology and the generation of a full-length toxin may help to address these issues.

\section{The First Complete Bont Locus in a Non-Clostridial Organism}

The finding of the orf1 gene in W. oryzae SG25 suggests that BoNT homologous sequences may be more widespread in the environment than previously appreciated. Indeed, the presence of BoNT-like genes in unusual species indicates that bont loci may move into different bacteria via gene transfer events. In line with this possibility, Brunt et al. and Williamsons et al. have recently reported the presence of a complete bont gene cluster, tentatively named eBoNT/J, in the genome of Enterococcus sp. 3G1_DIV0629, isolated in South Carolina (USA) from cow feces $[117,118]$. The most closely related species of this strain is Enterococcus faecium, a commensal bacterium often found in the gut lumen of terrestrial animals (including humans), yet strain 3G1_DIV0629 is the unique out of $>1000$ Enterococcus species in containing the bont gene cluster. Interestingly, species of Enterococcus like clostridia belong to the phylum of Firmicutes, but to the order of Lactobacillales like W. oryzae, indicating that the bont genes may have some preferential tropism for this order. The predicted neurotoxin gene product, despite low sequence identity ( $38 \%$ similar to BoNT $/ \mathrm{X})$, includes all the functional domains and shares many features of a typical BoNT, including the two cysteines for the interchain disulfide bond, the ganglioside binding pocket and the metallopeptidase motif (Table 1). Conversely, the binding domain, like in BoNT/X and BoNT/Wo, is rather different, indicating a peculiar targeting mechanism. Moreover, all open reading frames of the toxin cluster are intact, suggesting a likely possible expression.

Back-to-back with the publication of Brunt et al., Zhang et al. published a paper reporting the biological characterization of the same putative neurotoxin $(\mathrm{eBoNT} / \mathrm{J})$, that was now dubbed "BoNT/En" [119]. They found that BoNT/En (i.e., eBoNT/J) is not recognized by the standard BoNT 
antisera (including BoNT $/ \mathrm{X}$ ) and that it cleaves in vitro VAMP-1/-2/-3 to a conserved peptide bond A67-D68, very close to BoNT/X cleavage site. Interestingly, Zhang et al. showed that BoNT/En (i.e., eBoNT/J) also cleaves, although less efficiently, syntaxin-1B and syntaxin-4 (K191-D192) and SNAP-23/25 (K69-D70) (Table 1). Syntaxin cleavage is not maintained in living neurons, where only VAMP-2 and SNAP-25 are hydrolyzed. This result indicates BoNT/En (i.e., eBoNT/J) as the first toxin that potentially cleaves all three SNARE proteins. In addition, it is the first BoNT reported to cleave SNAP-25 at the N-terminus rather than at the C-terminus. BoNT/En (i.e., eBoNT/J) seems not to be toxic in mice, however, a chimeric toxin composed by the $\mathrm{H}$ chain of BoNT/A and the L chain of BoNT/En leads to paralysis and induces botulism symptoms, suggesting that this putative BoNT may display a different binding mechanism or even a different cell target.

The discovery of a botulinum-like toxin in Enterococcus species may be more than the tip of a large iceberg, with the possibility that many others will be identified in the future.

\section{Engineering BoNTs: Potential for Novel Therapeutic Applications}

Since the pioneering application in ophthalmology by Scott et al. in $1990[120,121]$, the clinical use of BoNTs has been continuously evolving. In modern medicine, BoNTs represent multipurpose therapeutic agents for the treatment of neurogenic movement disorders, neurosecretory, urologic, orthopedic, gastrointestinal, dental and pain conditions, with a large part of these applications being off-label [1,9]. Moreover, BoNTs have become very popular in cosmetics. Notably, all these applications are almost exclusively based on the use of BoNT/A1, as it provides the most persistent activity. Only in very few cases, almost exclusively due to the development of resistance to BoNT/A1, BoNT/B1 is used but with less success because it displays a much less convenient pharmacological profile, at least for neuromuscular disorders, as it requires higher doses and it has a much shorter duration $[1,89]$. Eleopra et al. were the first to explore the potential use of other BoNTs for human therapy [122-125]. It was shown that BoNT/C has a pharmacological profile similar to BoNT/A1, with similar potency and equal duration of action, whereas BoNT/E1 and BoNT/F1 produce a much shorter effect, even shorter than BoNT/B1. Intriguingly, BoNT/D, which is the most potent toxin type in rodents [1], was reported to be almost completely ineffective at the human neuromuscular junction and to cleave human VAMP-1 to a very low extent, explaining why very few cases of human botulism were linked to this toxin [66,126-129]. A unique study showed comparable activity of BoNT/D to BoNT/A, BoNT / B and BoNT/E [130]. Since insensitivity to BoNT/D by human muscles has been linked to a point mutation in VAMP-1, the study of Anderson opens up the possibility that polymorphism on human VAMP-1 gene may be responsible for this discrepancy. However, a recent study reported that human SNARE proteins do not present polymorphisms and are rather refractory to mutations, thus ruling out this possibility [131]. Altogether, these results indicate that BoNT/C represents a suitable alternative to BoNT/A, and that other BoNTs, like BoNT/E or /F, may be used when a short duration of action is preferable. BoNT subtypes are also considered an interesting avenue to explore. Indeed, among the many variants isolated so far, only a few have been characterized (mainly of the BoNT/A family) and they were found to display significantly different toxicological (thus pharmacological) properties [81-84]. In general, subtypes represent a potential goldmine to improve the current clinical use of BoNTs.

An important aspect of BoNTs is their protein nature and, in general, the possibility to be easily engineered and produced by recombinant methods [132]. Several laboratories are working in this direction and reported interesting results. Chen et al. and Sikorra et al. performed mutagenesis on BoNT/E and BoNT / A, respectively, to adapt their L chains to human SNAP-23, normally refractory to cleavage. They isolated cleaving mutants representing a solid base for the development of novel derivatives for the treatment SNAP-23-mediated hypersecretory disorders [133,134]. Wang et al. generated BoNT/AE chimeras (BoNT/A light chain, BoNT/E binding domain) to prolong the activity of BoNT/E [135]. BoNT/AB chimeras (BoNT/A light chain, BoNT/B binding domain) were used by Wang et al. to reduce exocytosis from non-neuronal cells expressing the BoNT/A-acceptor and 
utilizing VAMP, but not SNAP-25, in exocytosis [136], and by Kutschenko et al. to combine the high binding affinity of BoNT/B for autonomic nerve terminals and the long-lasting activity of BoNT/A light chain, thus developing a toxin to improve the treatment of autonomic disorders [137]. Pirazzini et al. produced a BoNT/B1 mutated in the translocation domain, which displayed higher potency than the wild type [138]. Tao et al. engineered the binding domain of BoNT/B1 to increase its affinity for human synaptotagmin-2, obtaining a mutant toxin with much higher activity in neurons expressing human synaptotagmin II [139]. More recently, Zanetti et al. showed that BoNT/C mutants with decreased activity against SNAP-25 display markedly low lethality but still maintain a long lasting neuromodulatory activity at the neuromuscular junction [93]. Accordingly, syntaxin-specific BoNTs represent a putative class of neurotoxins that can attenuate nerve terminal activity without affecting the overall functionality of the muscle, a picture of remarkable value in BoNT therapy.

Furthermore, the multidomain architecture makes BoNTs suitable platforms to be exploited for intracellular delivery of exogenous proteins. Proof of principle was provided by Bade et al., who engineered BoNT/D, fusing various proteins to its $L$ chain. Translocation of protein cargoes inside neuronal cytosol was efficient, with the only constraint that the cargo must be able to undergo unfolding [140]. Similar examples have been also provided by others [141-144]. Alternatively, specific fragments of BoNTs can be produced and rejoined by using a "protein-stapling" technology to combine distinct parts of different BoNTs (and possibly other targeting proteins), still maintaining enzymatic activity of the L chain $[145,146]$.

In general, these studies show how a few substitutions in amino acid sequence can functionally affect BoNTs biological activities, and how versatile BoNTs are to generate novel toxins with new and improved pharmacological features. In this direction, future structural and biochemical data on both the newly discovered serotype BoNT/X as well as on botulinum-like toxins, such as BoNT/Wo and BoNT/En, may open exciting avenues for original and currently unexpected therapeutic applications for human diseases.

\section{Conclusions}

The improvement in DNA sequencing techniques, together with bioinformatics and data-mining tools, are expanding our understanding on the diversity of BoNTs [17]. Surprisingly, BoNTs and BoNT-related genes have been reported in many different bacterial species outside of the genus Clostridium, including Weissella oryzae, Enterococcus faecium, Mycobacterium chelonae and Actinobacteria $[18,111,117,119,147,148]$. Despite this breakthrough, most of these toxin genes remain sequenced only and their products have not yet been tested. However, these species may have the potential to produce "BoNT-like toxins" displaying some similarity with the multidomain organization of BoNTs but different specificity, working principles and toxicological features. For instance, a recent report found another putative BoNT-like toxin in the genome of Chryseobacterium piperi (designed as $\mathrm{Cp} 1$ toxin), which retains structural homology to BoNTs, but it was shown to cause necrotic cell death in a human kidney embryonic cell line, without cleaving any SNARE proteins [148].

In light of these recent findings, it is tempting to speculate that BoNT-like genes and toxins may represent an early branching of BoNT evolution and that the modular domain architecture along with the neurotropism may have emerged more recently, possibly together with the evolution of the vertebrate nervous system. The specificity of BoNTs for neuronal SNARE proteins, dictated by multiple interactions between the L chains and their substrates, may derive from a BoNT ancestor with a much broader protease activity. The broad activity against multiple isoforms of VAMP and several SNARE proteins of the BoNT/X and BoNT/En is in agreement with this possibility. In this scenario, the identification of the substrate(s) of BoNT-like toxins, together with the characterization of their putative cell host(s), may provide new insights about how BoNTs have evolved. At the same time, it cannot be excluded that "classical BoNTs" can have alternative substrates different from SNARE proteins, and their discovery may further contribute to decipher BoNT evolution. However, the most important insight would be that of understanding the biological/ecological role(s) and 
the adaptive significance of BoNTs in clostridia. Even though it cannot be ruled out that toxigenicity and pathogenicity of BoNTs may be accidental, indeed it is presently unknown what adaptive advantages BoNTs provide to the clostridia life cycle [16]. The predominant explanation relies on the killing of vertebrate animals that are transformed into large anaerobic fermenters, expanding the anaerobic environment where toxigenic and non-toxigenic clostridia can proliferate. Yet, this does not explain the coevolution of so many BoNT serotypes and variants: how and why BoNTs have evolved remains a fascinating issue to be addressed. Future studies may shed light on the biological and toxicological features of BoNTs and BoNT-like proteins, and a comprehensive phylogeny may provide hints on the role of BoNTs and their evolutionary origin.

Author Contributions: D.A.T. and M.P. wrote and discussed the manuscript.

Acknowledgments: We thank A.M. for careful editing of the manuscript. The authors apologize to colleagues whose work could not be cited owing to space limitations. Research in the authors' laboratory is supported by the University of Padova (DOR) and the Italian Ministry of Defense (NIB2). D.A.T. is currently supported by an Alexander von Humboldt (AvH) Research Fellowship for Postdoctoral Researcher.

Conflicts of Interest: The authors declare no conflict of interest. The founding sponsors had no role in the design of the study, in the collection, analyses, or interpretation of data, in the writing of the manuscript, and in the decision to publish the results.

\section{References}

1. Pirazzini, M.; Rossetto, O.; Eleopra, R.; Montecucco, C. Botulinum neurotoxins: Biology, pharmacology, and toxicology. Pharmacol. Rev. 2017, 69, 200-235. [CrossRef] [PubMed]

2. Rossetto, O.; Pirazzini, M.; Montecucco, C. Botulinum neurotoxins: Genetic, structural and mechanistic insights. Nat. Rev. Microbiol. 2014, 12, 535-549. [CrossRef] [PubMed]

3. Johnson, E.A.; Montecucco, C. Botulism. Handb. Clin. Neurol. 2008, 91, 333-368. [PubMed]

4. Sutton, R.B.; Fasshauer, D.; Jahn, R.; Brunger, A.T. Crystal structure of a SNARE complex involved in synaptic exocytosis at 2.4 a resolution. Nature 1998, 395, 347-353. [CrossRef] [PubMed]

5. Südhof, T.C.; Rizo, J. Synaptic vesicle exocytosis. Cold Spring Harb. Perspect. Biol. 2011, 3. [CrossRef] [PubMed]

6. Schiavo, G.; Matteoli, M.; Montecucco, C. Neurotoxins affecting neuroexocytosis. Physiol. Rev. 2000, 80, 717-766. [CrossRef] [PubMed]

7. Hallett, M.; Albanese, A.; Dressler, D.; Segal, K.R.; Simpson, D.M.; Truong, D.; Jankovic, J. Evidence-based review and assessment of botulinum neurotoxin for the treatment of movement disorders. Toxicon 2013, 67, 94-114. [CrossRef] [PubMed]

8. Naumann, M.; Dressler, D.; Hallett, M.; Jankovic, J.; Schiavo, G.; Segal, K.R.; Truong, D. Evidence-based review and assessment of botulinum neurotoxin for the treatment of secretory disorders. Toxicon 2013, 67, 141-152. [CrossRef] [PubMed]

9. Jankovic, J. Botulinum toxin: State of the art. Mov. Disord. 2017, 32, 1131-1138. [CrossRef] [PubMed]

10. Rossetto, O.; Seveso, M.; Caccin, P.; Schiavo, G.; Montecucco, C. Tetanus and botulinum neurotoxins: Turning bad guys into good by research. Toxicon 2001, 39, 27-41. [CrossRef]

11. Caleo, M.; Restani, L. Exploiting botulinum neurotoxins for the study of brain physiology and pathology. Toxins 2018, 10, 175. [CrossRef] [PubMed]

12. Rothman, J.E. The principle of membrane fusion in the cell (nobel lecture). Angew. Chem. Int. Ed. Engl. 2014, 53, 12676-12694. [CrossRef] [PubMed]

13. Arnon, S.S.; Schechter, R.; Inglesby, T.V.; Henderson, D.A.; Bartlett, J.G.; Ascher, M.S.; Eitzen, E.; Fine, A.D.; Hauer, J.; Layton, M.; et al. Botulinum toxin as a biological weapon: Medical and public health management. JAMA 2001, 285, 1059-1070. [CrossRef] [PubMed]

14. Smith, T.J.; Hill, K.K.; Raphael, B.H. Historical and current perspectives on clostridium botulinum diversity. Res. Microbiol. 2015, 166, 290-302. [CrossRef] [PubMed]

15. Peck, M.W.; Smith, T.J.; Anniballi, F.; Austin, J.W.; Bano, L.; Bradshaw, M.; Cuervo, P.; Cheng, L.W.; Derman, Y.; Dorner, B.G.; et al. Historical perspectives and guidelines for botulinum neurotoxin subtype nomenclature. Toxins 2017, 9, 38. [CrossRef] [PubMed] 
16. Montecucco, C.; Rasotto, M.B. On botulinum neurotoxin variability. MBio 2015, 6, e02131-14. [CrossRef] [PubMed]

17. Mansfield, M.J.; Doxey, A.C. Genomic insights into the evolution and ecology of botulinum neurotoxins. Pathog. Dis. 2018. [CrossRef] [PubMed]

18. Doxey, A.C.; Mansfield, M.J.; Montecucco, C. Discovery of novel bacterial toxins by genomics and computational biology. Toxicon 2018, 147, 2-12. [CrossRef] [PubMed]

19. Lacy, D.B.; Tepp, W.; Cohen, A.C.; DasGupta, B.R.; Stevens, R.C. Crystal structure of botulinum neurotoxin type a and implications for toxicity. Nat. Struct. Biol. 1998, 5, 898-902. [CrossRef] [PubMed]

20. Swaminathan, S.; Eswaramoorthy, S. Structural analysis of the catalytic and binding sites of clostridium botulinum neurotoxin b. Nat. Struct. Biol. 2000, 7, 693-699. [CrossRef] [PubMed]

21. Rummel, A. Two feet on the membrane: Uptake of clostridial neurotoxins. Curr. Top. Microbiol. Immunol. 2016, 406, 1-37.

22. Binz, T.; Rummel, A. Cell entry strategy of clostridial neurotoxins. J. Neurochem. 2009, 109, $1584-1595$. [CrossRef] [PubMed]

23. Muraro, L.; Tosatto, S.; Motterlini, L.; Rossetto, O.; Montecucco, C. The n-terminal half of the receptor domain of botulinum neurotoxin a binds to microdomains of the plasma membrane. Biochem. Biophys. Res. Commun. 2009, 380, 76-80. [CrossRef] [PubMed]

24. Zhang, Y.; Varnum, S.M. The receptor binding domain of botulinum neurotoxin serotype c binds phosphoinositides. Biochimie 2012, 94, 920-923. [CrossRef] [PubMed]

25. Yao, G.; Zhang, S.; Mahrhold, S.; Lam, K.; Stern, D.; Bagramyan, K.; Perry, K.; Kalkum, M.; Rummel, A.; Dong, M.; et al. N-linked glycosylation of SV2 is required for binding and uptake of botulinum neurotoxin A. Nat. Struct. Mol. Biol. 2016, 23, 656-662. [CrossRef] [PubMed]

26. Montecucco, C.; Zanotti, G. Botulinum neurotoxin a1 likes it double sweet. Nat. Struct. Mol. Biol. 2016, 23, 619. [CrossRef] [PubMed]

27. Fischer, A.; Montal, M. Molecular dissection of botulinum neurotoxin reveals interdomain chaperone function. Toxicon 2013, 75, 101-107. [CrossRef] [PubMed]

28. Montal, M. Botulinum neurotoxin: A marvel of protein design. Annu. Rev. Biochem. 2010, 79, 591-617. [CrossRef] [PubMed]

29. Pirazzini, M.; Azarnia Tehran, D.; Leka, O.; Zanetti, G.; Rossetto, O.; Montecucco, C. On the translocation of botulinum and tetanus neurotoxins across the membrane of acidic intracellular compartments. Biochim. Biophys. Acta 2016, 1858, 467-474. [CrossRef] [PubMed]

30. Pantano, S.; Montecucco, C. The blockade of the neurotransmitter release apparatus by botulinum neurotoxins. Cell. Mol. Life Sci. 2013, 71, 793-811. [CrossRef] [PubMed]

31. Binz, T. Clostridial neurotoxin light chains: Devices for SNARE cleavage mediated blockade of neurotransmission. Curr. Top. Microbiol. Immunol. 2013, 364, 139-157. [PubMed]

32. Schiavo, G.; Rossetto, O.; Santucci, A.; DasGupta, B.R.; Montecucco, C. Botulinum neurotoxins are zinc proteins. J. Biol. Chem. 1992, 267, 23479-23483. [PubMed]

33. Simpson, L. The life history of a botulinum toxin molecule. Toxicon 2013, 68, 40-59. [CrossRef] [PubMed]

34. Pirazzini, M.; Rossetto, O. Challenges in searching for therapeutics against botulinum neurotoxins. Exp. Opin. Drug Discov. 2017, 12, 497-510. [CrossRef] [PubMed]

35. Pirazzini, M.; Azarnia Tehran, D.; Zanetti, G.; Rossetto, O.; Montecucco, C. Hsp90 and thioredoxin-thioredoxin reductase enable the catalytic activity of clostridial neurotoxins inside nerve terminals. Toxicon 2017, 147, 32-37. [CrossRef] [PubMed]

36. Pirazzini, M.; Azarnia Tehran, D.; Zanetti, G.; Lista, F.; Binz, T.; Shone, C.C.; Rossetto, O.; Montecucco, C. The thioredoxin reductase-Thioredoxin redox system cleaves the interchain disulphide bond of botulinum neurotoxins on the cytosolic surface of synaptic vesicles. Toxicon 2015, 107, 32-36. [CrossRef] [PubMed]

37. Montecucco, C. How do tetanus and botulinum toxins bind to neuronal membranes? Trends Biochem. Sci. 1986, 11, 314-317. [CrossRef]

38. Benoit, R.M.; Frey, D.; Hilbert, M.; Kevenaar, J.T.; Wieser, M.M.; Stirnimann, C.U.; McMillan, D.; Ceska, T.; Lebon, F.; Jaussi, R.; et al. Structural basis for recognition of synaptic vesicle protein $2 \mathrm{c}$ by botulinum neurotoxin a. Nature 2014, 505, 108-111. [CrossRef] [PubMed]

39. Kammerer, R.A.; Benoit, R.M. Botulinum neurotoxins: New questions arising from structural biology. Trends Biochem. Sci. 2014, 39, 517-526. [CrossRef] [PubMed] 
40. Dong, M.; Yeh, F.; Tepp, W.H.; Dean, C.; Johnson, E.A.; Janz, R.; Chapman, E.R. SV2 is the protein receptor for botulinum neurotoxin a. Science 2006, 312, 592-596. [CrossRef] [PubMed]

41. Dong, M.; Liu, H.; Tepp, W.H.; Johnson, E.A.; Janz, R.; Chapman, E.R. Glycosylated SV2A and SV2B mediate the entry of botulinum neurotoxin e into neurons. Mol. Biol. Cell 2008, 19, 5226-5237. [CrossRef] [PubMed]

42. Nishiki, T.; Kamata, Y.; Nemoto, Y.; Omori, A.; Ito, T.; Takahashi, M.; Kozaki, S. Identification of protein receptor for clostridium botulinum type b neurotoxin in rat brain synaptosomes. J. Biol. Chem. 1994, 269, 10498-10503. [PubMed]

43. Peng, L.; Berntsson, R.P.; Tepp, W.H.; Pitkin, R.M.; Johnson, E.A.; Stenmark, P.; Dong, M. Botulinum neurotoxin $\mathrm{d}-\mathrm{c}$ uses synaptotagmin $\mathrm{i}$ and ii as receptors, and human synaptotagmin ii is not an effective receptor for type b, d-c and g toxins. J. Cell Sci. 2012, 125, 3233-3242. [CrossRef] [PubMed]

44. Rummel, A.; Karnath, T.; Henke, T.; Bigalke, H.; Binz, T. Synaptotagmins i and ii act as nerve cell receptors for botulinum neurotoxin g. J. Biol. Chem. 2004, 279, 30865-30870. [CrossRef] [PubMed]

45. Mahrhold, S.; Bergstrom, T.; Stern, D.; Dorner, B.G.; Astot, C.; Rummel, A. Only the complex n559-glycan in the synaptic vesicle glycoprotein $2 \mathrm{c}$ mediates high affinity binding to botulinum neurotoxin serotype a1. Biochem. J. 2016, 473, 2645-2654. [CrossRef] [PubMed]

46. Pucic, M.; Pinto, S.; Novokmet, M.; Knezevic, A.; Gornik, O.; Polasek, O.; Vlahovicek, K.; Wang, W.; Rudd, P.M.; Wright, A.F.; et al. Common aberrations from the normal human plasma n-glycan profile. Glycobiology 2010, 20, 970-975. [CrossRef] [PubMed]

47. Knezevic, A.; Polasek, O.; Gornik, O.; Rudan, I.; Campbell, H.; Hayward, C.; Wright, A.; Kolcic, I.; O'Donoghue, N.; Bones, J.; et al. Variability, heritability and environmental determinants of human plasma n-glycome. J. Proteom. Res. 2009, 8, 694-701. [CrossRef] [PubMed]

48. Lauc, G.; Pezer, M.; Rudan, I.; Campbell, H. Mechanisms of disease: The human n-glycome. Biochim. Biophys. Acta 2015, 1860, 1574-1582. [CrossRef] [PubMed]

49. Zhang, S.; Berntsson, R.P.A.; Tepp, W.H.; Tao, L.; Johnson, E.A.; Stenmark, P.; Dong, M. Structural basis for the unique ganglioside and cell membrane recognition mechanism of botulinum neurotoxin dc. Nat. Commun. 2017, 8, 1637. [CrossRef] [PubMed]

50. Nakamura, K.; Kohda, T.; Umeda, K.; Yamamoto, H.; Mukamoto, M.; Kozaki, S. Characterization of the $\mathrm{d} / \mathrm{c}$ mosaic neurotoxin produced by clostridium botulinum associated with bovine botulism in Japan. Vet. Microbiol. 2010, 140, 147-154. [CrossRef] [PubMed]

51. Kroken, A.R.; Karalewitz, A.P.; Fu, Z.; Kim, J.J.; Barbieri, J.T. Novel ganglioside-mediated entry of botulinum neurotoxin serotype d into neurons. J. Biol. Chem. 2011, 286, 26828-26837. [CrossRef] [PubMed]

52. Peng, L.; Tepp, W.H.; Johnson, E.A.; Dong, M. Botulinum neurotoxin d uses synaptic vesicle protein SV2 and gangliosides as receptors. PLoS Pathog. 2011, 7, e1002008. [CrossRef] [PubMed]

53. Strotmeier, J.; Lee, K.; Volker, A.K.; Mahrhold, S.; Zong, Y.; Zeiser, J.; Zhou, J.; Pich, A.; Bigalke, H.; Binz, T.; et al. Botulinum neurotoxin serotype d attacks neurons via two carbohydrate-binding sites in a ganglioside-dependent manner. Biochem. J. 2010, 431, 207-216. [CrossRef] [PubMed]

54. Tsukamoto, K.; Kohda, T.; Mukamoto, M.; Takeuchi, K.; Ihara, H.; Saito, M.; Kozaki, S. Binding of clostridium botulinum type $\mathrm{c}$ and $\mathrm{d}$ neurotoxins to ganglioside and phospholipid. Novel insights into the receptor for clostridial neurotoxins. J. Biol. Chem. 2005, 280, 35164-35171. [CrossRef] [PubMed]

55. Kroken, A.R.; Karalewitz, A.P.; Fu, Z.; Baldwin, M.R.; Kim, J.J.; Barbieri, J.T. Unique ganglioside binding by botulinum neurotoxins c and d-sa. FEBS J. 2011, 278, 4486-4496. [CrossRef] [PubMed]

56. Karalewitz, A.P.; Kroken, A.R.; Fu, Z.; Baldwin, M.R.; Kim, J.J.; Barbieri, J.T. Identification of a unique ganglioside binding loop within botulinum neurotoxins c and d-sa. Biochemistry 2010, 49, 8117-8126. [CrossRef] [PubMed]

57. Colasante, C.; Rossetto, O.; Morbiato, L.; Pirazzini, M.; Molgo, J.; Montecucco, C. Botulinum neurotoxin type a is internalized and translocated from small synaptic vesicles at the neuromuscular junction. Mol. Neurobiol. 2013, 48, 120-127. [CrossRef] [PubMed]

58. Harper, C.B.; Papadopulos, A.; Martin, S.; Matthews, D.R.; Morgan, G.P.; Nguyen, T.H.; Wang, T.; Nair, D.; Choquet, D.; Meunier, F.A. Botulinum neurotoxin type-a enters a non-recycling pool of synaptic vesicles. Sci. Rep. 2016, 6, 19654. [CrossRef] [PubMed]

59. Harper, C.B.; Martin, S.; Nguyen, T.H.; Daniels, S.J.; Lavidis, N.A.; Popoff, M.R.; Hadzic, G.; Mariana, A.; Chau, N.; McCluskey, A.; et al. Dynamin inhibition blocks botulinum neurotoxin type a endocytosis in neurons and delays botulism. J. Biol. Chem. 2011, 286, 35966-35976. [CrossRef] [PubMed] 
60. Koriazova, L.K.; Montal, M. Translocation of botulinum neurotoxin light chain protease through the heavy chain channel. Nat. Struct. Biol. 2003, 10, 13-18. [CrossRef] [PubMed]

61. Pirazzini, M.; Rossetto, O.; Bolognese, P.; Shone, C.C.; Montecucco, C. Double anchorage to the membrane and intact inter-chain disulfide bond are required for the low ph induced entry of tetanus and botulinum neurotoxins into neurons. Cell. Microbiol. 2011, 13, 1731-1743. [CrossRef] [PubMed]

62. Sun, S.; Suresh, S.; Liu, H.; Tepp, W.H.; Johnson, E.A.; Edwardson, J.M.; Chapman, E.R. Receptor binding enables botulinum neurotoxin $\mathrm{b}$ to sense low ph for translocation channel assembly. Cell Host Microbe 2011, 10, 237-247. [CrossRef] [PubMed]

63. Fischer, A.; Montal, M. Crucial role of the disulfide bridge between botulinum neurotoxin light and heavy chains in protease translocation across membranes. J. Biol. Chem. 2007, 282, 29604-29611. [CrossRef] [PubMed]

64. Azarnia Tehran, D.; Pirazzini, M.; Leka, O.; Mattarei, A.; Lista, F.; Binz, T.; Rossetto, O.; Montecucco, C. Hsp90 is involved in the entry of clostridial neurotoxins into the cytosol of nerve terminals. Cell. Microbiol. 2017, 19. [CrossRef] [PubMed]

65. Zanetti, G.; Azarnia Tehran, D.; Pirazzini, M.; Binz, T.; Shone, C.C.; Fillo, S.; Lista, F.; Rossetto, O.; Montecucco, C. Inhibition of botulinum neurotoxins interchain disulfide bond reduction prevents the peripheral neuroparalysis of botulism. Biochem. Pharmacol. 2015, 98, 522-530.

66. Eleopra, R.; Montecucco, C.; Devigili, G.; Lettieri, C.; Rinaldo, S.; Verriello, L.; Pirazzini, M.; Caccin, P.; Rossetto, O. Botulinum neurotoxin serotype $\mathrm{d}$ is poorly effective in humans: An in vivo electrophysiological study. Clin. Neurophysiol. 2013, 124, 999-1004. [CrossRef] [PubMed]

67. Van Ermengem, E. Ueber einen neuen anaëroben bacillus und seine beziehungen zum botulismus. Med. Microbiol. Immunol. 1897, 26, 1-56. [CrossRef]

68. Erbguth, F.J. Historical notes on botulism, clostridium botulinum, botulinum toxin, and the idea of the therapeutic use of the toxin. Mov. Disord. 2004, 19, S2-S6. [CrossRef] [PubMed]

69. Moriishi, K.; Koura, M.; Fujii, N.; Fujinaga, Y.; Inoue, K.; Syuto, B.; Oguma, K. Molecular cloning of the gene encoding the mosaic neurotoxin, composed of parts of botulinum neurotoxin types $\mathrm{c} 1$ and $\mathrm{d}$, and pcr detection of this gene from clostridium botulinum type c organisms. Appl. Environ. Microbiol. 1996, 62, 662-667. [PubMed]

70. Moriishi, K.; Koura, M.; Abe, N.; Fujii, N.; Fujinaga, Y.; Inoue, K.; Ogumad, K. Mosaic structures of neurotoxins produced from clostridium botulinum types c and d organisms. Biochim. Biophys. Acta 1996, 1307, 123-126. [CrossRef]

71. Hedeland, M.; Moura, H.; Båverud, V.; Woolfitt, A.R.; Bondesson, U.; Barr, J.R. Confirmation of botulism in birds and cattle by the mouse bioassay and endopep-ms. J. Med. Microbiol. 2011, 60, 1299-1305. [CrossRef] [PubMed]

72. Nakamura, K.; Kohda, T.; Seto, Y.; Mukamoto, M.; Kozaki, S. Improved detection methods by genetic and immunological techniques for botulinum c/d and d/c mosaic neurotoxins. Vet. Microbiol. 2013, 162, 881-890. [CrossRef] [PubMed]

73. Takeda, M.; Tsukamoto, K.; Kohda, T.; Matsui, M.; Mukamoto, M.; Kozaki, S. Characterization of the neurotoxin produced by isolates associated with avian botulism. Avian Dis. 2005, 49, 376-381. [CrossRef] [PubMed]

74. Woudstra, C.; Le Maréchal, C.; Souillard, R.; Bayon-Auboyer, M.-H.; Mermoud, I.; Desoutter, D.; Fach, P. New insights into the genetic diversity of clostridium botulinum group iii through extensive genome exploration. Front. Microbiol. 2016, 7, 757. [CrossRef] [PubMed]

75. Williamson, C.H.; Sahl, J.W.; Smith, T.J.; Xie, G.; Foley, B.T.; Smith, L.A.; Fernandez, R.A.; Lindstrom, M.; Korkeala, H.; Keim, P.; et al. Comparative genomic analyses reveal broad diversity in botulinum-toxin-producing clostridia. BMC Genom. 2016, 17, 180. [CrossRef] [PubMed]

76. Hill, K.K.; Smith, T.J. Genetic diversity within clostridium botulinum serotypes, botulinum neurotoxin gene clusters and toxin subtypes. Curr. Top. Microbiol. Immunol. 2013, 364, 1-20. [PubMed]

77. Hill, K.K.; Smith, T.J.; Helma, C.H.; Ticknor, L.O.; Foley, B.T.; Svensson, R.T.; Brown, J.L.; Johnson, E.A.; Smith, L.A.; Okinaka, R.T.; et al. Genetic diversity among botulinum neurotoxin-producing clostridial strains. J. Bacteriol. 2007, 189, 818-832. [CrossRef] [PubMed] 
78. Giordani, F.; Fillo, S.; Anselmo, A.; Palozzi, A.M.; Fortunato, A.; Gentile, B.; Azarnia Tehran, D.; Ciammaruconi, A.; Spagnolo, F.; Pittiglio, V.; et al. Genomic characterization of italian clostridium botulinum group i strains. Infect. Genet. Evol. 2015, 36, 62-71. [CrossRef] [PubMed]

79. Fillo, S.; Giordani, F.; Anniballi, F.; Gorge, O.; Ramisse, V.; Vergnaud, G.; Riehm, J.M.; Scholz, H.C.; Splettstoesser, W.D.; Kieboom, J.; et al. Clostridium botulinum group i strain genotyping by 15-locus multilocus variable-number tandem-repeat analysis. J. Clin. Microbiol. 2011, 49, 4252-4263. [CrossRef] [PubMed]

80. Whitemarsh, R.C.; Tepp, W.H.; Johnson, E.A.; Pellett, S. Persistence of botulinum neurotoxin a subtypes 1-5 in primary rat spinal cord cells. PLoS ONE 2014, 9, e90252. [CrossRef] [PubMed]

81. Wang, D.; Krilich, J.; Pellett, S.; Baudys, J.; Tepp, W.H.; Barr, J.R.; Johnson, E.A.; Kalb, S.R. Comparison of the catalytic properties of the botulinum neurotoxin subtypes a1 and a5. Biochim. Biophys. Acta 2013, 1834, 2722-2728. [CrossRef] [PubMed]

82. Whitemarsh, R.C.; Tepp, W.H.; Bradshaw, M.; Lin, G.; Pier, C.L.; Scherf, J.M.; Johnson, E.A.; Pellett, S. Characterization of botulinum neurotoxin a subtypes 1 through 5 by investigation of activities in mice, in neuronal cell cultures, and in vitro. Infect. Immun. 2013, 81, 3894-3902. [CrossRef] [PubMed]

83. Pier, C.L.; Chen, C.; Tepp, W.H.; Lin, G.; Janda, K.D.; Barbieri, J.T.; Pellett, S.; Johnson, E.A. Botulinum neurotoxin subtype a2 enters neuronal cells faster than subtype a1. FEBS Lett. 2011, 585, 199-206. [CrossRef] [PubMed]

84. Pellett, S.; Tepp, W.H.; Whitemarsh, R.C.; Bradshaw, M.; Johnson, E.A. In vivo onset and duration of action varies for botulinum neurotoxin a subtypes 1-5. Toxicon 2015, 107, 37-42. [CrossRef] [PubMed]

85. Torii, Y.; Goto, Y.; Nakahira, S.; Kozaki, S.; Kaji, R.; Ginnaga, A. Comparison of systemic toxicity between botulinum toxin subtypes a1 and a2 in mice and rats. Basic Clin. Pharmacol. Toxicol. 2015, 116, 524-528. [CrossRef] [PubMed]

86. Kull, S.; Schulz, K.M.; Weisemann, J.; Kirchner, S.; Schreiber, T.; Bollenbach, A.; Dabrowski, P.W.; Nitsche, A.; Kalb, S.R.; Dorner, M.B.; et al. Isolation and functional characterization of the novel clostridium botulinum neurotoxin a8 subtype. PLoS ONE 2015, 10, e0116381. [CrossRef] [PubMed]

87. Kalb, S.R.; Baudys, J.; Webb, R.P.; Wright, P.; Smith, T.J.; Smith, L.A.; Fernández, R.; Raphael, B.H.; Maslanka, S.E.; Pirkle, J.L.; et al. Discovery of a novel enzymatic cleavage site for botulinum neurotoxin f5. FEBS Lett. 2012, 586, 109-115. [CrossRef] [PubMed]

88. Kozaki, S.; Kamata, Y.; Nishiki, T.; Kakinuma, H.; Maruyama, H.; Takahashi, H.; Karasawa, T.; Yamakawa, K.; Nakamura, $\mathrm{S}$. Characterization of clostridium botulinum type $\mathrm{b}$ neurotoxin associated with infant botulism in japan. Infect. Immun. 1998, 66, 4811-4816. [PubMed]

89. Bentivoglio, A.R.; Del Grande, A.; Petracca, M.; Ialongo, T.; Ricciardi, L. Clinical differences between botulinum neurotoxin type a and b. Toxicon 2015, 107, 77-84. [CrossRef] [PubMed]

90. Pang, Z.P.; Melicoff, E.; Padgett, D.; Liu, Y.; Teich, A.F.; Dickey, B.F.; Lin, W.; Adachi, R.; Sudhof, T.C. Synaptotagmin-2 is essential for survival and contributes to $\mathrm{Ca}^{2+}$ triggering of neurotransmitter release in central and neuromuscular synapses. J. Neurosci. 2006, 26, 13493-13504. [CrossRef] [PubMed]

91. Li, J.Y.; Jahn, R.; Dahlstrom, A. Synaptotagmin i is present mainly in autonomic and sensory neurons of the rat peripheral nervous system. Neuroscience 1994, 63, 837-850. [CrossRef]

92. Wang, D.; Zhang, Z.; Dong, M.; Sun, S.; Chapman, E.R.; Jackson, M.B. Syntaxin requirement for $\mathrm{Ca}^{2+}$-triggered exocytosis in neurons and endocrine cells demonstrated with an engineered neurotoxin. Biochemistry 2011, 50, 2711-2713. [CrossRef] [PubMed]

93. Zanetti, G.; Sikorra, S.; Rummel, A.; Krez, N.; Duregotti, E.; Negro, S.; Henke, T.; Rossetto, O.; Binz, T.; Pirazzini, M. Botulinum neurotoxin c mutants reveal different effects of syntaxin or snap-25 proteolysis on neuromuscular transmission. PLoS Pathog. 2017, 13, e1006567. [CrossRef] [PubMed]

94. Dover, N.; Barash, J.R.; Hill, K.K.; Xie, G.; Arnon, S.S. Molecular characterization of a novel botulinum neurotoxin type h gene. J. Infect. Dis. 2014, 209, 192-202. [CrossRef] [PubMed]

95. Barash, J.R.; Arnon, S.S. A novel strain of clostridium botulinum that produces type $\mathrm{b}$ and type h botulinum toxins. J. Infect. Dis. 2013, 209, 183-191. [CrossRef] [PubMed]

96. Johnson, E.A. Validity of botulinum neurotoxin serotype h. J. Infect. Dis. 2014, 210, 992-993. [CrossRef] [PubMed] 
97. Maslanka, S.E.; Lúquez, C.; Dykes, J.K.; Tepp, W.H.; Pier, C.L.; Pellett, S.; Raphael, B.H.; Kalb, S.R.; Barr, J.R.; Rao, A.; et al. A novel botulinum neurotoxin, previously reported as serotype $h$, has a hybrid-like structure with regions of similarity to the structures of serotypes a and $f$ and is neutralized with serotype a antitoxin. J. Infect. Dis. 2016, 213, 379-385. [CrossRef] [PubMed]

98. Kalb, S.R.; Baudys, J.; Raphael, B.H.; Dykes, J.K.; Luquez, C.; Maslanka, S.E.; Barr, J.R. Functional characterization of botulinum neurotoxin serotype $h$ as a hybrid of known serotypes $f$ and a (bont $f / a)$. Anal. Chem. 2015, 87, 3911-3917. [CrossRef] [PubMed]

99. Yao, G.; Lam, K.; Perry, K.; Weisemann, J.; Rummel, A.; Jin, R. Crystal structure of the receptor-binding domain of botulinum neurotoxin type ha, also known as type fa or h. Toxins 2017, 9, 93. [CrossRef] [PubMed]

100. Fan, Y.; Barash, J.R.; Lou, J.; Conrad, F.; Marks, J.D.; Arnon, S.S. Immunological characterization and neutralizing ability of monoclonal antibodies directed against botulinum neurotoxin type h. J. Infect. Dis. 2016, 213, 1606-1614. [CrossRef] [PubMed]

101. Pellett, S.; Tepp, W.H.; Bradshaw, M.; Kalb, S.R.; Dykes, J.K.; Lin, G.; Nawrocki, E.M.; Pier, C.L.; Barr, J.R.; Maslanka, S.E.; et al. Purification and characterization of botulinum neurotoxin fa from a genetically modified clostridium botulinum strain. mSphere 2016, 1, e00100-15. [CrossRef] [PubMed]

102. Pellett, S.; Tepp, W.H.; Lin, G.; Johnson, E.A. Substrate cleavage and duration of action of botulinum neurotoxin type fa ("h, ha”). Toxicon 2018, 147, 38-46. [CrossRef] [PubMed]

103. Kakinuma, H.; Maruyama, H.; Takahashi, H.; Yamakawa, K.; Nakamura, S. The first case of type b infant botulism in japan. Pediatr. Int. 1996, 38, 541-543. [CrossRef]

104. Umeda, K.; Seto, Y.; Kohda, T.; Mukamoto, M.; Kozaki, S. Stability of toxigenicity in proteolytic clostridium botulinum type b upon serial passage. Microbiol. Immunol. 2012, 56, 338-341. [CrossRef] [PubMed]

105. Zhang, S.; Masuyer, G.; Zhang, J.; Shen, Y.; Lundin, D.; Henriksson, L.; Miyashita, S.-I.; Martínez-Carranza, M.; Dong, M.; Stenmark, P. Identification and characterization of a novel botulinum neurotoxin. Nat. Commun. 2017, 8, 14130. [CrossRef] [PubMed]

106. Pellizzari, R.; Rossetto, O.; Lozzi, L.; Giovedi, S.; Johnson, E.; Shone, C.C.; Montecucco, C. Structural determinants of the specificity for synaptic vesicle-associated membrane protein/synaptobrevin of tetanus and botulinum type b and g neurotoxins. J. Biol. Chem. 1996, 271, 20353-20358. [CrossRef] [PubMed]

107. Rossetto, O.; Schiavo, G.; Montecucco, C.; Poulain, B.; Deloye, F.; Lozzi, L.; Shone, C.C. SNARE motif and neurotoxins. Nature 1994, 372, 415-416. [CrossRef] [PubMed]

108. Breidenbach, M.A.; Brunger, A.T. Substrate recognition strategy for botulinum neurotoxin serotype a. Nature 2004, 432, 925-929. [CrossRef] [PubMed]

109. Agarwal, R.; Schmidt, J.J.; Stafford, R.G.; Swaminathan, S. Mode of VAMP substrate recognition and inhibition of Clostridium botulinum neurotoxin f. Nat. Struct. Mol. Biol. 2009, 16, 789-794. [CrossRef] [PubMed]

110. Masuyer, G.; Zhang, S.; Barkho, S.; Shen, Y.; Henriksson, L.; Košenina, S.; Dong, M.; Stenmark, P. Structural characterisation of the catalytic domain of botulinum neurotoxin $\mathrm{x}$-High activity and unique substrate specificity. Sci. Rep. 2018, 8, 4518. [CrossRef] [PubMed]

111. Mansfield, M.J.; Adams, J.B.; Doxey, A.C. Botulinum neurotoxin homologs in non-clostridium species. FEBS Lett. 2015, 589, 342-348. [CrossRef] [PubMed]

112. Tohno, M.; Kitahara, M.; Irisawa, T.; Masuda, T.; Uegaki, R.; Ohkuma, M.; Tajima, K. Lactobacillus silagei sp. nov., isolated from orchardgrass silage. Int. J. Syst. Evol. Microbiol. 2013, 63, 4613-4618. [CrossRef] [PubMed]

113. Rigoni, M.; Caccin, P.; Johnson, E.A.; Montecucco, C.; Rossetto, O. Site-directed mutagenesis identifies active-site residues of the light chain of botulinum neurotoxin type a. Biochem. Biophys. Res. Commun. 2001, 288, 1231-1237. [CrossRef] [PubMed]

114. Zornetta, I.; Azarnia Tehran, D.; Arrigoni, G.; Anniballi, F.; Bano, L.; Leka, O.; Zanotti, G.; Binz, T.; Montecucco, C. The first non clostridial botulinum-like toxin cleaves VAMP within the juxtamembrane domain. Sci. Rep. 2016, 6, 30257. [CrossRef] [PubMed]

115. Bowen, M.; Brunger, A.T. Conformation of the synaptobrevin transmembrane domain. Proc. Natl. Acad. Sci. USA 2006, 103, 8378. [CrossRef] [PubMed]

116. Fang, Q.; Zhao, Y.; Lindau, M. Juxtamembrane tryptophans of synaptobrevin 2 control the process of membrane fusion. FEBS Lett. 2013, 587, 67-72. [CrossRef] [PubMed]

117. Brunt, J.; Carter, A.T.; Stringer, S.C.; Peck, M.W. Identification of a novel botulinum neurotoxin gene cluster in enterococcus. FEBS Lett. 2018, 592, 310-317. [CrossRef] [PubMed] 
118. Williamson, C.H.D.; Smith, T.J.; Foley, B.T.; Hill, K.; Keim, P.; Sahl, J.W. Botulinum-neurotoxin-like sequences identified from an Enterococcus sp. Genome assembly. bioRxiv 2017. [CrossRef]

119. Zhang, S.; Lebreton, F.; Mansfield, M.J.; Miyashita, S.I.; Zhang, J.; Schwartzman, J.A.; Tao, L.; Masuyer, G.; Martinez-Carranza, M.; Stenmark, P.; et al. Identification of a botulinum neurotoxin-like toxin in a commensal strain of enterococcus faecium. Cell Host Microbe 2018, 23, 169-176. [CrossRef] [PubMed]

120. Scott, A.B.; Rosenbaum, A.; Collins, C.C. Pharmacologic weakening of extraocular muscles. Investig. Ophthalmol. 1973, 12, 924-927.

121. Scott, A.B. Botulinum toxin injection into extraocular muscles as an alternative to strabismus surgery. Ophthalmology 1980, 87, 1044-1049. [CrossRef]

122. Eleopra, R.; Tugnoli, V.; Quatrale, R.; Rossetto, O.; Montecucco, C.; Dressler, D. Clinical use of non-a botulinum toxins: Botulinum toxin type $\mathrm{c}$ and botulinum toxin type f. Neurotox. Res. 2006, 9, 127-131. [CrossRef] [PubMed]

123. Eleopra, R.; Tugnoli, V.; Quatrale, R.; Rossetto, O.; Montecucco, C. Different types of botulinum toxin in humans. Mov. Disord. 2004, 19, S53-S59. [CrossRef] [PubMed]

124. Eleopra, R.; Tugnoli, V.; Rossetto, O.; De Grandis, D.; Montecucco, C. Different time courses of recovery after poisoning with botulinum neurotoxin serotypes a and e in humans. Neurosci. Lett. 1998, 256, 135-138. [CrossRef]

125. Eleopra, R.; Tugnoli, V.; Rossetto, O.; Montecucco, C.; De Grandis, D. Botulinum neurotoxin serotype c: A novel effective botulinum toxin therapy in human. Neurosci. Lett. 1997, 224, 91-94. [CrossRef]

126. Peng, L.; Adler, M.; Demogines, A.; Borrell, A.; Liu, H.; Tao, L.; Tepp, W.H.; Zhang, S.-C.; Johnson, E.A.; Sawyer, S.L.; et al. Widespread sequence variations in VAMP1 across vertebrates suggest a potential selective pressure from botulinum neurotoxins. PLoS Pathog. 2014, 10, e1004177. [CrossRef] [PubMed]

127. Yamamoto, H.; Ida, T.; Tsutsuki, H.; Mori, M.; Matsumoto, T.; Kohda, T.; Mukamoto, M.; Goshima, N.; Kozaki, S.; Ihara, H. Specificity of botulinum protease for human VAMP family proteins. Microbiol. Immunol. 2012, 56, 245-253. [CrossRef] [PubMed]

128. Coffield, J.A.; Bakry, N.; Zhang, R.D.; Carlson, J.; Gomella, L.G.; Simpson, L.L. In vitro characterization of botulinum toxin types a, $\mathrm{c}$ and d action on human tissues: Combined electrophysiologic, pharmacologic and molecular biologic approaches. J. Pharmacol. Exp. Ther. 1997, 280, 1489-1498. [PubMed]

129. Pellett, S.; Tepp, W.H.; Scherf, J.M.; Pier, C.L.; Johnson, E.A. Activity of botulinum neurotoxin type d (strain 1873) in human neurons. Toxicon 2015, 101, 63-69. [CrossRef] [PubMed]

130. Anderson, J.; Williams, P.T.; Katos, A.M.; Krasna, M.; Burrows, W.; Hilmas, C.J. Chapter 30—Botulinum toxin. In Handbook of Toxicology of Chemical Warfare Agents; Gupta, R.C., Ed.; Academic Press: San Diego, CA, USA, 2009; pp. 407-432.

131. Carle, S.; Pirazzini, M.; Rossetto, O.; Barth, H.; Montecucco, C. High conservation of tetanus and botulinum neurotoxins cleavage sites on human SNARE proteins suggests that these pathogens exerted little or no evolutionary pressure on humans. Toxins 2017, 9, 404. [CrossRef] [PubMed]

132. Masuyer, G.; Chaddock, J.A.; Foster, K.A.; Acharya, K.R. Engineered botulinum neurotoxins as new therapeutics. Annu. Rev. Pharmacol. Toxicol. 2014, 54, 27-51. [CrossRef] [PubMed]

133. Sikorra, S.; Litschko, C.; Muller, C.; Thiel, N.; Galli, T.; Eichner, T.; Binz, T. Identification and characterization of botulinum neurotoxin a substrate binding pockets and their re-engineering for human snap-23. J. Mol. Biol. 2016, 428, 372-384. [CrossRef] [PubMed]

134. Chen, S.; Barbieri, J.T. Engineering botulinum neurotoxin to extend therapeutic intervention. Proc. Natl. Acad. Sci. USA 2009, 106, 9180-9184. [CrossRef] [PubMed]

135. Wang, J.; Meng, J.; Lawrence, G.W.; Zurawski, T.H.; Sasse, A.; Bodeker, M.O.; Gilmore, M.A.; Fernández-Salas, E.; Francis, J.; Steward, L.E.; et al. Novel chimeras of botulinum neurotoxins a and e unveil contributions from the binding, translocation, and protease domains to their functional characteristics. J. Biol. Chem. 2008, 283, 16993-17002. [CrossRef] [PubMed]

136. Wang, J.; Zurawski, T.H.; Bodeker, M.O.; Meng, J.; Boddul, S.; Aoki, K.R.; Dolly, J.O. Longer-acting and highly potent chimaeric inhibitors of excessive exocytosis created with domains from botulinum neurotoxin A and B. Biochem. J. 2012, 444, 59. [CrossRef] [PubMed]

137. Kutschenko, A.; Reinert, M.-C.; Krez, N.; Liebetanz, D.; Rummel, A. Bont/ab hybrid maintains similar duration of paresis as bont/a wild-type in murine running wheel assay. NeuroToxicology 2017, 59, 1-8. [CrossRef] [PubMed] 
138. Pirazzini, M.; Henke, T.; Rossetto, O.; Mahrhold, S.; Krez, N.; Rummel, A.; Montecucco, C.; Binz, T. Neutralisation of specific surface carboxylates speeds up translocation of botulinum neurotoxin type $\mathrm{b}$ enzymatic domain. FEBS Lett. 2013, 587, 3831-3836. [CrossRef] [PubMed]

139. Tao, L.; Peng, L.; Berntsson, R.P.A.; Liu, S.M.; Park, S.; Yu, F.; Boone, C.; Palan, S.; Beard, M.; Chabrier, P.-E.; et al. Engineered botulinum neurotoxin $b$ with improved efficacy for targeting human receptors. Nat. Commun. 2017, 8, 53. [CrossRef] [PubMed]

140. Bade, S.; Rummel, A.; Reisinger, C.; Karnath, T.; Ahnert-Hilger, G.; Bigalke, H.; Binz, T. Botulinum neurotoxin type $\mathrm{d}$ enables cytosolic delivery of enzymatically active cargo proteins to neurones via unfolded translocation intermediates. J. Neurochem. 2004, 91, 1461-1472. [CrossRef] [PubMed]

141. Masuyer, G.; Davies, J.R.; Moore, K.; Chaddock, J.A.; Ravi Acharya, K. Structural analysis of clostridium botulinum neurotoxin type $\mathrm{d}$ as a platform for the development of targeted secretion inhibitors. Sci. Rep. 2015, 5, 13397. [CrossRef] [PubMed]

142. Vazquez-Cintron, E.J.; Beske, P.H.; Tenezaca, L.; Tran, B.Q.; Oyler, J.M.; Glotfelty, E.J.; Angeles, C.A.; Syngkon, A.; Mukherjee, J.; Kalb, S.R.; et al. Engineering botulinum neurotoxin c1 as a molecular vehicle for intra-neuronal drug delivery. Sci. Rep. 2017, 7, 42923. [CrossRef] [PubMed]

143. O’Leary, V.B.; Ovsepian, S.V.; Raghunath, A.; Huo, Q.; Lawrence, G.W.; Smith, L.; Dolly, J.O. Innocuous full-length botulinum neurotoxin targets and promotes the expression of lentiviral vectors in central and autonomic neurons. Gene Ther. 2011, 18, 656. [CrossRef] [PubMed]

144. Nugent, M.; Wang, J.; Lawrence, G.; Zurawski, T.; Geoghegan, J.A.; Dolly, J.O. Conjugate of an igg binding domain with botulinum neurotoxin a lacking the acceptor moiety targets its SNARE protease into trka-expressing cells when coupled to anti-trka igg or fc-ßngf. Bioconjug. Chem. 2017, 28, 1684-1692. [CrossRef] [PubMed]

145. Ferrari, E.; Maywood, E.S.; Restani, L.; Caleo, M.; Pirazzini, M.; Rossetto, O.; Hastings, M.H.; Niranjan, D.; Schiavo, G.; Davletov, B. Re-assembled botulinum neurotoxin inhibits cns functions without systemic toxicity. Toxins 2011, 3, 345-355. [CrossRef] [PubMed]

146. Darios, F.; Niranjan, D.; Ferrari, E.; Zhang, F.; Soloviev, M.; Rummel, A.; Bigalke, H.; Suckling, J.; Ushkaryov, Y.; Naumenko, N.; et al. Snare tagging allows stepwise assembly of a multimodular medicinal toxin. Proc. Natl. Acad. Sci. USA 2010, 107, 18197-18201. [CrossRef] [PubMed]

147. Wentz, T.G.; Muruvanda, T.; Lomonaco, S.; Thirunavukkarasu, N.; Hoffmann, M.; Allard, M.W.; Hodge, D.R.; Pillai, S.P.; Hammack, T.S.; Brown, E.W.; et al. Closed genome sequence of Chryseobacterium piperi strain CTM(T)/ATCC BAA-1782, a gram-negative bacterium with clostridial neurotoxin-like coding sequences. Genome Announc. 2017, 5, e01296-17. [CrossRef] [PubMed]

148. Mansfield, M.J.; Wentz, T.G.; Zhang, S.; Lee, E.J.; Dong, M.; Sharma, S.K.; Doxey, A.C. Newly identified relatives of botulinum neurotoxins shed light on their molecular evolution. bioRxiv 2017. [CrossRef] 